\title{
Modeling denitrification in aquatic sediments
}

\author{
Katja Fennel · Damian Brady · Dominic DiToro $\cdot$ Robinson W. Fulweiler • \\ Wayne S. Gardner • Anne Giblin · Mark J. McCarthy • Alexandra Rao • \\ Sybil Seitzinger $\cdot$ Marie Thouvenot-Korppoo $\cdot$ Craig Tobias
}

Received: 18 January 2008/Accepted: 8 August 2008/Published online: 10 December 2008

(C) Springer Science+Business Media B.V. 2008

\begin{abstract}
Sediment denitrification is a major pathway of fixed nitrogen loss from aquatic systems. Due to technical difficulties in measuring this process and its spatial and temporal variability, estimates of local, regional and global denitrification have to rely on a combination of measurements and models. Here we review approaches to describing denitrification in aquatic sediments, ranging from mechanistic
\end{abstract}

Electronic supplementary material The online version of this article (doi:10.1007/s10533-008-9270-z) contains supplementary material, which is available to authorized users.

K. Fennel ( $\square)$

Department of Oceanography, Dalhousie University, 1355 Oxford St, Halifax, NS, Canada B3H 4J1

e-mail: katja.fennel@dal.ca

D. Brady · D. DiToro

University of Delaware, Newark, DE, USA

R. W. Fulweiler

Louisiana State University, Baton Rouge, LA, USA

W. S. Gardner · M. J. McCarthy

Marine Science Institute, The University of Texas at

Austin Port, Aransas, TX, USA

A. Giblin

Marine Biological Laboratory Ecosystems Center,

Woods Hole, MA, USA

Present Address:

M. J. McCarthy

Département Sciences Biologiques, Université du Québec

à Montréal, Montréal, QC, Canada diagenetic models to empirical parameterizations of nitrogen fluxes across the sediment-water interface. We also present a compilation of denitrification measurements and ancillary data for different aquatic systems, ranging from freshwater to marine. Based on this data compilation we reevaluate published parameterizations of denitrification. We recommend that future models of denitrification use (1) a combination of mechanistic diagenetic models and measurements where bottomwaters are temporally hypoxic or anoxic, and (2) the much simpler correlations between denitrification and sediment oxygen consumption for oxic bottom waters.
A. Rao
Woods Hole Oceanographic Institution, Woods Hole, MA, USA
S. Seitzinger
Institute of Marine and Coastal Sciences, Rutgers/NOAA CMER Program, Rutgers University, New Brunswick, NJ, USA
M. Thouvenot-Korppoo
Water Resources Engineering, Helsinki University
of Technology, Helsinki, Finland
C. Tobias
University of North Carolina Wilmington, Wilmington, NC, USA 
For our data set, inclusion of bottom water oxygen and nitrate concentrations in a multivariate regression did not improve the statistical fit.

Keywords Denitrification - Diagenetic model · Sediment

$\begin{array}{ll}\text { Abbreviations } \\ \text { DNRA } & \begin{array}{l}\text { Dissimalatory nitrate } \\ \text { reduction to ammonium }\end{array} \\ \text { ODUs } & \text { Oxygen-demand units } \\ \text { SFM } & \text { Sediment flux model } \\ \text { SOC } & \text { Sediment oxygen consumption }\end{array}$

\section{Introduction}

Unlike other important macro- and micronutrients, e.g., phosphorus and iron, the reservoir of bioavailable nitrogen is regulated almost solely by biological activity. Two opposing, microbially mediated processes, denitrification and nitrogen fixation, regulate the size of this reservoir. Nitrogen is the major limiting nutrient in marine systems; thus, variations in its availability have far-reaching consequences. Denitrification is any process by which combined nitrogen (nitrate, ammonium or organic forms) is reduced to gaseous end products $\left(\mathrm{NO}, \mathrm{N}_{2} \mathrm{O}\right.$ or $\mathrm{N}_{2}$ ) (Devol 2008). In the more restrictive, classical definition, denitrification is a dissimilatory nitrate reduction process during which nitrate or nitrite $\left(\mathrm{NO}_{3}{ }^{-}\right.$or $\left.\mathrm{NO}_{2}{ }^{-}\right)$is reduced anaerobically to any gaseous form of nitrogen by heterotrophic bacteria (also referred to as canonical denitrification). It is carried out by ubiquitous, facultatively anaerobic bacteria under suboxic conditions (i.e. at oxygen concentrations below approximately $2 \mathrm{mg} \mathrm{O}_{2} \mathrm{l}^{-1}$ or $63 \mathrm{mmol} \mathrm{O}_{2} \mathrm{~m}^{-3}$ ) and its end product is $\mathrm{N}_{2}$ gas. Denitrification in sediments containing ample labile organic matter is often limited by the availability of nitrate or nitrite. Available fixed nitrogen in sediments is mostly in the form of ammonium $\left(\mathrm{NH}_{4}{ }^{+}\right.$, derived from ammonification of organic matter or dissimilatory nitrate reduction to ammonium under some conditions). Unless there is a flux of nitrate into the sediment from overlying bottom waters, denitrification in the sediment depends on local rates of nitrification (the oxidation of ammonium to nitrite or nitrate by chemoautotrophic bacteria). This combination of processes is commonly referred to as coupled nitrification-denitrification. Denitrification supported by the physical influx of nitrate is referred to as direct denitrification.

Denitrification is the major pathway of fixed nitrogen loss from aquatic systems. Thus, it is a critical component of the global nitrogen budget and a balancing mechanism for removal of anthropogenic nitrogen along the terrestrial-freshwater-marine continuum (Galloway et al. 2003; Seitzinger et al. 2006). On the global scale, denitrification is an important feedback mechanism on biogeochemical cycling and in the climate system. For example, denitrification may have been a major impediment to the initial oxidation of the planet during the suboxic stage in the Proterozoic (Fennel et al. 2005). Denitrification can produce nitrous oxide $\left(\mathrm{N}_{2} \mathrm{O}\right.$, a potent greenhouse gas), which can have important impacts on climate (Naqvi et al. 2000). In addition, denitrification may contribute to glacial-interglacial changes in atmospheric $\mathrm{CO}_{2}$ by decreasing the supply of bioavailable nitrogen and, thus, biologically fixed carbon during interglacial periods (Altabet et al. 1995; Falkowski 1997).

Anaerobic ammonium oxidation (anammox) by nitrite or nitrate has been identified as an alternative microbial pathway of $\mathrm{N}_{2}$ production and, from a biogeochemical perspective, can be considered a denitrifying process (Devol 2008). The possibility of anammox was originally suggested by Richards et al. (1965) and invoked by various investigators based on pore water solute profiles (Bender et al. 1989) before the discovery of organisms that can carry out this process. Anammox was first observed in a wastewater bioreactor (Mulder et al. 1995). Anammox organisms have been purified from wastewater reactor biomass and identified in several natural marine systems, such as the suboxic zone of the Black Sea and the Benguela upwelling system (Kuypers et al. 2003; Kuypers et al. 2005 and references therein), and in Randers Fjord, Denmark (Risgaard-Petersen et al. 2004). The significance of anammox was demonstrated in a variety of coastal and marine sediments (Thamdrup and Dalsgaard 2002; Trimmer et al. 2003, 2005; Dalsgaard et al. 2003; Engström et al. 2005). In the following discussions, we adopt the biogeochemical view of denitrification (inclusive of all processes producing $\mathrm{N}_{2}$ ) and do not differentiate between the alternative pathways. 
A first attempt to estimate annual denitrification on a global scale was made recently with a spatially explicit global analysis of denitrification in all terrestrial, freshwater (lakes/rivers), estuarine and shelf ecosystems using various models (Seitzinger et al. 2006). A global estimate of denitrification in lakes and reservoirs is presented by Harrison et al. (2008). These models are largely based on empirical relationships, e.g., in Harrison et al. (2008) nitrogen removal is estimated from knowledge of water depth and residence time in individual lakes and reservoirs. Boyer et al. (2006) review approaches for modeling denitrification in terrestrial and aquatic ecosystems, and focused on source-transport models for streams, lakes and rivers. These models aggregate nitrogen removal processes estimated from empirical functions (typically denitrification is parameterized as a function of water residence time) but do not explicitly account for the production and cycling of organic nitrogen.

Here we describe approaches to estimating denitrification that predict nitrogen fluxes across the sediment-water interface and can be incorporated into hydrographic ecosystem models that explicitly describe inorganic and organic nitrogen cycling in the water column. Hydrographic ecosystem models that focus on estuaries or continental shelves tend to consider the pathways of sediment nitrogen cycling, (e.g., DiToro and Fitzpatrick 1993; Cerco and Seitzinger 1997; Fennel et al. 2006). Global and basin-scale biogeochemical models typically ignore sediment denitrification even though this process has been recognized as an important global nitrogen sink (Christensen 1994) and is estimated to exceed denitrification in the water column by a factor of 3 (Seitzinger et al. 2006). For example, Meissner et al. (2005) and Moore and Doney (2007) investigate feedbacks between global denitrification and nitrogen fixation in biogeochemical general circulation models without the inclusion of sediment denitrification.

Placing denitrification in aquatic sediments in the broader and more complex context of early diagenesis is helpful. Diagenesis can be considered, "the sum total of processes that bring about changes in a sediment or sedimentary rock, subsequent to deposition in water. The processes may be physical, chemical, and/or biological in nature" (Berner 1980 , p. 3). Diagenetic processes thus include transport and reaction processes; both can be the result of biological and physical phenomena (Boudreau 1997).

Progress in our understanding of diagenetic processes has rested on a close link between observational approaches and diagenetic modeling, i.e., the idealized mathematical representation of diagenetic processes (Berner 1980). Boudreau (1997) offers several reasons for the important role of diagenetic modeling, several of which are relevant to denitrification. First, many measurements do not provide information about the interactions of the various processes; they only indicate the net result. With the help of models one can make quantitative inferences about the relative importance or absence of individual processes. Second, sampling techniques often disturb the system under consideration. Many processes are transient and hard to resolve. Denitrification measurements are particularly time consuming and imprecise, mostly because they either try to measure a small production rate of $\mathrm{N}_{2}$ against the high background of atmospheric $\mathrm{N}_{2}$ or use indirect measurements as a proxy for denitrification. Finally, trusted models can become tools for prediction. As such, models allow scaling up from local measurements to larger spatial and temporal scales. A strong link between measurement and modeling is crucial.

Excellent reviews on diagenetic modeling have been provided by Berner (1980), Boudreau (1997), DiToro (2001) and Burdige (2006) and will not be replicated here. Our objectives are (1) to review approaches to diagenetic modeling with a focus on denitrification, (2) to compile a data set of denitrification measurements and sediment-water fluxes of oxygen and different nutrient species that encompasses a range of aquatic sediments, and (3) test the robustness of empirical parameterizations and evaluate one example of a mechanistically based diagenetic model against the compiled data set.

\section{Model approaches}

Denitrification depends on and interacts with a range of other processes occurring in aquatic sediments (e.g., supply of organic matter, diffusive and advective transport of oxygen and nitrate, nitrification). Our discussion of quantitative descriptions of denitrification in aquatic sediments is thus best placed in the context of early diagenesis. We refer to these quantitative descriptions of sediment denitrification 
as diagenetic models or biogeochemical sediment models, but recognize that denitrification is just one of many diagenetic processes. When assessing the importance of sediment denitrification in nitrogen cycling we are interested primarily in the sedimentwater interface fluxes of nitrogen species; oxidation and reduction of other elements is not discussed here. For simplicity, we refer to the sum of nitrite $\left(\mathrm{NO}_{2}{ }^{-}\right)$ and nitrate $\left(\mathrm{NO}_{3}{ }^{-}\right)$as nitrate.

Many different approaches to modeling early diagenetic processes exist. In terms of temporal representation, diagenetic models can be steady-state (concentrations and fluxes are constant in time) or dynamic (the model allows for temporal variations in concentrations and fluxes). In terms of spatial representation, models often consider spatial variations only in the vertical dimension. They assume horizontal homogeneity. In simple cases, the differential equations representing early diagenesis can be solved analytically and yield vertically continuous solutions. These are typically steady-state models with simple reaction kinetics. More often the diagenetic equations are not amenable to analytical solutions. In these cases, the vertical dimension is discretized in vertical layers and solved numerically. In essence the layers represent a vertical integration over processes and constituents in a vertical slice of sediment. These slices can be functional or indiscriminate layers. Functional layers can be defined by the occurrence of a reaction process or the presence of a dissolved constituent, e.g., an anaerobic and an aerobic layer. Indiscriminate layers are strictly defined in terms of their vertical coordinates and assume different functions; e.g., they can switch between aerobic mineralization and denitrification depending on the local oxygen concentration.

Alternative approaches that attempt to account for three-dimensional heterogeneities have been proposed, e.g., representing anaerobic microenvironments within individual particles in an otherwise aerobic environment, or the representation of animal burrows (Aller 1980, 1988).

All of these models aim to describe a subset of the occurring diagenetic processes and fluxes across the sediment-water interface. Early diagenetic models were developed independent of water column biogeochemical models and, to this day, biogeochemical models still rarely include diagenetic processes (see the excellent review by Soetaert et al. 2000).
Biogeochemical models that do include some form of diagenesis typically use parameterizations (e.g., Fennel et al. 2006), which can be thought of as the most simplified quantitative description of early diagenesis.

The general diagenetic equations for solid constituents, $S$, and dissolved constituents in the pore water, $C$, following Berner (1980) are:

$$
\begin{aligned}
\frac{\partial(1-\phi) S}{\partial t}= & -\frac{\partial}{\partial z}\left((1-\phi) w_{\mathrm{sed}} S\right) \\
& +\frac{\partial}{\partial z}\left((1-\phi) D_{\mathrm{B}} \frac{\partial S}{\partial z}\right)+\sum R(S, C)
\end{aligned}
$$

$$
\begin{aligned}
\frac{\partial \phi C}{\partial t}= & -\frac{\partial}{\partial z}\left(\phi w_{\mathrm{PW}} C\right)+\frac{\partial}{\partial z}\left(\phi D \frac{\partial C}{\partial z}\right) \\
& +\sum R(S, C)
\end{aligned}
$$

Here $\phi$ is the porosity (the fraction of sediment volume that is liquid), a dimensionless number that varies between 0 and 1 . The dissolved constituent $C$ has units of mol m $\mathrm{m}^{-3}$ of pore water only and is multiplied by $\phi$ to convert to $\mathrm{mol} \mathrm{m}^{-3}$ of sediment (pore water + solid). $C$ represents, e.g., the concentrations of oxygen, nitrate or ammonium. Likewise, the solid $S$ has units of mol $\mathrm{m}^{-3}$ of solid only and is multiplied by $1-\phi$ to convert to mol $\mathrm{m}^{-3}$ of sediment. $S$ represents, e.g., organic carbon or biogenic silicate. The time-rate-ofchange of solid and dissolved constituents (left-hand sides of Eq. 1a, b) equals the sum of changes due to vertical advection (first set of terms on the right hand side [rhs]), diffusive processes (second set of terms on rhs) and transformations due to biogeochemical reactions (collected in the term $\sum R(S, C)$ ). The advection velocities of solids and pore water are $w_{\text {sed }}$ and $w_{\mathrm{PW}}$, respectively. Bioturbation of solids (i.e., the "mixing" of sediment by the burrowing action of higher animals) is often described as a diffusive mixing process with diffusivity $D_{\mathrm{B}}$. $D$ is the pore water diffusivity.

Steady-state models

Steady-state models (e.g., Jahnke et al. 1982; Middelburg et al. 1996; Soetaert et al. 1996b; Vanderborght et al. 1977a, b) are an application of the general diagenetic Eq. (1a, b), where the left-hand-side is set to equal zero, thus eliminating the time dependence. Some of these models have been solved analytically, some numerically. An elegant analytical solution to a 
diagenetic equation of denitrification was derived by Vanderborght et al. (1977a, b), for fine-grained, organically rich, coastal sediments in the North Sea. Since the top $3.5 \mathrm{~cm}$ of sediment at their site appeared to go through a continuous cycle of deposition and erosion due to the action of waves and currents, the authors chose an elevated diffusivity in the welloxygenated top layer and a diffusivity more typical of pore water below. By solving the model analytically for silica, fitting their solution to observed pore water profiles, they obtained an appropriate value for the diffusivity in the top layer, which was then used in solving the nitrate equation. This example illustrates two points: (1) processes other than molecular diffusion and bioturbation can cause vertical mixing of sediment (an accurate parameterization of the vertical mixing processes is important for making reasonable predictions of denitrification rates); and (2) the distribution of an independent variable, in this case dissolved silica, can provide a means to determine a reasonable parameterization for diffusivity. In essence, the silica distribution adds independent information to the parameterization.

An example of a steady-state model that is more complex biogeochemically and has to be solved numerically is that of Middelburg et al. (1996). Their model explicitly resolves the depth distribution of solid-phase organic carbon and nitrogen, and pore water concentrations of oxygen, nitrate and ammonium. Reduced manganese, iron and sulfur are lumped into oxygen-demand units (ODUs). ODUs are oxidized when they come in contact with oxygen and are transported similarly to the other dissolved substances. This choice allows one to include the net effect of manganese, iron and sulpfur cycles on the oxygen distribution without having to explicitly model their complex interactions. By assuming global values for model parameters and applying one porosity profile globally, Middelburg et al. (1996) arrived at a general parameterization of denitrification and estimated the global rate of sediment denitrification.

Layered dynamic models

Dynamic representations of functional layers, e.g., in the Sediment Flux Model (SFM, DiToro and Fitzpatrick 1993; DiToro 2001), or indiscriminate layers (e.g., in the model of Soetaert et al. 1996a) are based on the diagenetic Eq. 1a, b as well.
In the SFM (DiToro and Fitzpatrick 1993; DiToro 2001) the sediment is represented by two functional layers: an aerobic layer directly below the sedimentwater interface and an anaerobic layer below. Concentration changes of solid and dissolved constituents are described by mass balance equations where the change of a constituent within a given volume is related to the sum of internal sources and sinks of the constituent (i.e., internal reactions) and its fluxes across the volume boundaries. Essentially, the mass balance equations are discrete representations of the continuous diagenetic equations. For example, diffusive processes-which are parameterized by multiplying a diffusivity, $D$, with the concentration gradient $\partial c / \partial z$ in the continuous case (see Eq. 1a, b) - become mass transfer coefficients in the layered case. The mass transfer rate for oxygen is parameterized as the ratio of the computed sediment oxygen demand and the dissolved oxygen concentration in the overlying bottom water and the surface mass transfer rates for all other dissolved constituents are assumed to be equal to the transfer rate derived for oxygen (DiToro 2001).

The sediment model in Riverstrahler, a model of nutrient cycling in a river system (Billen et al. 1994; Garnier et al. 1995; Billen and Garnier 1999), is an example for a vertically integrated (1-layer) diagenetic model. In Riverstrahler, the representation of a river drainage network is coupled with models of biogeochemical transformations in the river's water column and underlying sediment (Ruelland et al. 2007). The sediment in Riverstahler is represented by one layer of deposited and erodable particulate material assumed to be homogeneously distributed along the vertical dimension and overlying a layer of consolidated non-erodable sediment. The sediment model is solved in quasi-steady-state mode, i.e., the sediment model is assumed to reach steady-state during each sediment model time step. This assumption simplifies the treatment of the diagenetic equations significantly, as most equations can be solved analytically (Thouvenot et al. 2007).

\section{Microenvironments}

All approaches discussed above assume that processes are local and occur along the vertical dimension, with rates of diagenetic processes varying only with vertical gradients in solute concentrations 
or redox conditions. This assumption has been used traditionally and may be valid for some sediment types, e.g., muddy sediments and clays. However, it is not a good assumption for permeable sands, which comprise $\sim 70 \%$ of continental shelves worldwide (Emery 1968). Solute exchange in muddy sediments is driven by molecular diffusion and macrofaunal activity (mixing and pore water irrigation), but the high permeabilities of sandy deposits permit pore water transport by advection (Thibodeaux and Boyle 1987; Boudreau 1997). Pore water flows in these sediments are linked to pressure gradients associated with current-topography interactions, wave pumping, groundwater discharge, temperature and salinity gradients, and other factors (Huettel and Webster 2001). Advective flows enhance the supply of oxidants and fresh organic matter, and the removal of remineralization byproducts (e.g., $\mathrm{CO}_{2}$ and reduced electron acceptors) from $>10 \mathrm{~cm}$ depth in these organically poor deposits, resulting in intense metabolic activity (Jahnke et al. 2005; Rao et al. 2007). Some studies have shown microscale spatial heterogeneity in sediment denitrification rates (Parkin 1987; Gold et al. 1998; Jacinthe et al. 1998).

Jahnke (1985) published a steady-state model of denitrification in sediment microenvironments based on Jorgensen (1977), in which reactive microenvironments in fecal pellets or other organic aggregates are represented as spherical particles of specified diameter, porosity and reactivity, within which organic matter respiration, and chemical and biologically mediated redox transformations occur. The distribution, reactivity and physical characteristics of these reactive particles in sediments are therefore important unknown parameters, which nonetheless must be specified in the model.

Model results were compared to pore water solute profiles measured in fine-grained deep-sea sediments (Jahnke 1985). This spherical microzone model may be applied in other modeling frameworks, e.g., in dynamic models, to simulate microzone denitrification.

\section{Parameterizations}

Different parameterizations of denitrification have been proposed where denitrification is a function of one or more environmental factors that can be measured readily or estimated. Such parameterizations are useful because they can predict denitrification rates over large spatial and temporal scales, and in the absence of detailed information. Such parameterizations can also easily be incorporated into regional and large-scale biogeochemical models. Two examples are (1) a regression between sediment oxygen consumption and denitrification for estuarine, coastal ocean and continental shelf regions (Seitzinger et al. 2006); and (2) a regression between organic matter sedimentation flux and denitrification for the open ocean (Middelburg et al. 1996). These regressions have been used directly to provide snapshots of shelf-scale and global-scale denitrification, and as parameterizations in dynamics models (e.g., Fennel et al. 2006).

Middelburg et al. (1996, see also our 'Steady-state models' subsection, above) used a steady-state diagenetic model to derive global rates of denitrification in marine sediments. They used two different parameterizations, one where sediment denitrification depends on organic matter sedimentation only, and one where it depends on organic matter sedimentation, bottom water oxygen, and nitrate concentrations and water depth. For the purpose of deriving a general parameterization, the authors assumed global values for rate parameters, limitation and inhibition parameters, and assumed one porosity profile to be globally applicable. Some parameters were chosen as water depth dependent, namely the sediment accumulation rate, the bioturbation rate and the flux of labile carbon. A sensitivity study revealed that model-predicted denitrification rates depend most strongly on the sedimentation flux and bottom-water concentrations of nitrate and oxygen. The authors arrived at their parameterization by multivariate regression of model-predicted sediment denitrification rates and model inputs (sedimentation flux, bottom water concentrations, depth). A large number of model solutions were used in the regression and were derived by randomly varying model parameters (within specified intervals), bottom-water nitrate and oxygen concentrations, and organic matter carbon fluxes.

Organic matter sedimentation flux is a useful descriptor for the open ocean and (possibly) deep lakes, but it is of limited use for shallow aquatic systems (e.g., shallow lakes, wetlands, rivers, estuaries and the nearshore coastal ocean), because organic matter typically settles and is resuspended multiple times before being respired or buried. This cycle of settling and resuspension is, at best, difficult to measure or quantify. Sediment oxygen consumption 
is more easily measured, is closely related to the oxidation of organic carbon in sediments and, hence, is more useful for shallow systems.

A parameterization for coupled nitrification-denitrification for continental shelf sediments was derived based on measured rates of denitrification and sediment oxygen consumption from different continental shelf regions by Seitzinger et al. (2006). This parameterization was used to estimate the spatial distribution of denitrification throughout shelf regions in the North Atlantic basin and suggests that sediment denitrification is greater than nitrogen inputs from atmospheric deposition and river sources combined, indicating that on-welling of deep water nitrate is a major nitrogen source for denitrification on shelves. This parameterization was subsequently used in a biogeochemical model for the continental shelf area of the North American east coast by Fennel et al. (2006), who transformed it into a regression between denitrification and organic matter flux, as this is the relevant quantity predicted by the biogeochemical model. It was assumed that organic matter is remineralized instantaneously upon reaching the sediment-water interface and that sediment oxygen consumption occurs only in the oxidation of carbon and the nitrification of ammonium. The same assumptions can be used to reformulate the parameterization of Middelburg et al. (1996) in terms of sediment oxygen consumption (SOC). We compare both of these parameterizations with our data compilation below ('Environmental control on $\mathrm{N}$ cycling processes').

\section{Data}

Data compilation

We synthesized a relatively large set of measured denitrification rates with ancillary measurements, including our own unpublished data and data available in the literature. As a minimum requirement for a data point to be considered useful, both denitrification and sediment oxygen consumption rates had to be available coincidentally. Our data set contains 657 data points that meet this minimum requirement. We also compiled $\sim 463$ data points with coincident measurements of nitrate, ammonium and phosphate fluxes between sediment and bottom water, and bottom water concentrations of oxygen and nitrate. For some of these points, additional information, such as sediment type or primary productivity rates, are available as well.

Our data originate from different aquatic environments, ranging from freshwater systems (Lake Champlain and Old Woman Creek, Lake Erie) and brackish waters (Chesapeake Bay and Corpus Christi Bay, Gulf of Mexico) to oceanic continental shelves (Arctic, Washington and Middle Atlantic Bight shelves and the East China Sea). Data sources, site descriptions and measurement techniques are listed in Table 1. The data compilation is included as Supplementary Online Material. Denitrification rates were determined by measuring $\mathrm{N}_{2}$ :Ar ratios with membrane-inlet mass spectrometry (MIMS; Kana et al. 1994, 1998), except for the data from Lake Champlain, the University of Rhode Island (URI) mesocosm experiments, Chesapeake Bay and the East China Sea. For data from Lake Champlain, the URI mesocosms and Chesapeake Bay, we calculated denitrification assuming Redfield stoichiometry for organic matter remineralization and a respiratory coefficient of one (one mol organic carbon remineralized per mol $\mathrm{O}_{2}$ consumed). We assume that denitrification accounts for the deficit in dissolved inorganic nitrogen flux from the sediment with respect to the flux expected based on organic matter remineralization (using sediment oxygen consumption as reference; see Table 2). For the data from the East China Sea we calculated denitrification as the difference between the production rate of ammonium and the sediment efflux of ammonium and nitrate (see Table 2).

\section{Mean tendencies}

On average, the sediments in our data collection are a net sink of bioavailable nitrogen with a mean and median denitrification rate of 2.2 and $1.5 \mathrm{mmol} \mathrm{N} \mathrm{m} \mathrm{N}^{-2}$, respectively, and consumed oxygen at a mean and median rate of 27.0 and $20.1 \mathrm{mmol} \mathrm{O}_{2} \mathrm{~m}^{-2} \mathrm{~d}^{-1}$, respectively (Figs. 1c, 2a). On average, the flux of nitrate and phosphate into bottom waters is negligible, with median fluxes of $0.06 \mathrm{mmol} \mathrm{NO}_{3} \mathrm{~m}^{-2} \mathrm{~d}^{-1}$ and $0.03 \mathrm{mmol} \mathrm{PO}_{4} \mathrm{~m}^{-2} \mathrm{~d}^{-1}$ (Fig. 1, phosphate flux not shown). Recycled bioavailable nitrogen is returned to the bottom water as ammonium at mean and median rates of 2.0 and $0.84 \mathrm{mmol} \mathrm{N} \mathrm{m} \mathrm{N}^{-2} \mathrm{~d}^{-1}$, respectively (Fig. 1b).

There are 39 data points with net nitrogen fixation in our data set; 15 from Narragansett Bay sediments, 22 
Table 1 Data sources, measurement methods and references

Region Salinity Measurement technique

Site Description (\# of data points)

Measurement technique

Lake Champlain (15)

0

Old Woman Creek

0

Hypereutrophic wetland, Lake Erie (72)

Chesapeake Bay

$15-20$

Eutrophic, seasonally hypoxic estuary (82)

\section{Corpus Christi Bay}

Estuary on the shoreline of the Gulf of Mexico (55)

Narragansett Bay

Mid-Atlantic Bight inner shelf (93)

New Jersey Shelf

Coastal ocean in the Mid-Atlantic Bight (20)

Mesocosms

Facility at the Univ. of Rhode Island (139)

Boston Harbor

Gulf of Maine inner shelf (32)

Massachusetts Bay

Gulf of Maine inner shelf (48)

Gulf of Mexico

Coastal, seasonally hypoxic ocean (36)

Mississippi River Plume

Gulf of Mexico (4)

South Atlantic Bight (4)

East China Sea (21)

Oceanic

Different shelf and open ocean regions (41)

Washington Shelf

Oceanic

Oceanic

Continental shelf (17)

Western Arctic Shelf

Continental shelf (22)
Box core samples were taken; fluxes and overlying water concentrations of $\mathrm{NH}_{4}, \mathrm{NO}_{3}, \mathrm{PO}_{4}, \mathrm{O}_{2}$ were measured; methods described in Cornwell and Owens (1999); tabulated data from DiToro (2001)

Sediment cores were incubated in a continuous-flow system; $\mathrm{N}_{2}: \mathrm{Ar}$ ratios were measured with membrane-inlet mass spectrometry (MIMS); data from McCarthy et al. (2007)

Box core samples were taken; fluxes and overlying water concentrations of $\mathrm{NH}_{4}, \mathrm{NO}_{3}, \mathrm{PO}_{4}, \mathrm{O}_{2}$ were measured; methods described in Cowan and Boynton (1996); tabulated data from DiToro (2001)

Sediment cores were incubated in a continuous-flow system; $\mathrm{N}_{2}$ : $\mathrm{Ar}$ ratios were measured with MIMS; data from McCarthy et al. (2008)

Sediment cores were incubated; $\mathrm{N}_{2}: \mathrm{Ar}$ ratios were measured with MIMS; data from Fulweiler et al. (2007); Fulweiler (2007); Fulweiler and Nixon (2008)

In situ benthic chambers; $\mathrm{N}_{2}$ :Ar ratios measured with MIMS; data from Laursen and Seitzinger (2002)

Fluxes and overlying water concentrations of $\mathrm{NH}_{4}, \mathrm{NO}_{3}, \mathrm{PO}_{4}, \mathrm{O}_{2}$ were measured in mesocosms; data from the Nutrient Addition Experiment (Oviatt et al. 1986); tabulated data from DiToro (2001)

Sediment cores were incubated at in situ temperatures; fluxes of $\mathrm{O}_{2}$, $\mathrm{PO}_{4}, \mathrm{NH}_{4}, \mathrm{NO}_{3}+\mathrm{NO}_{2}$ were measured using standard techniques (Giblin et al. 1997); $\mathrm{N}_{2}$ :Ar ratios measured with MIMS

Same as Boston Harbor

Sediment cores were incubated in a continuous-flow system; $\mathrm{N}_{2}$ : Ar ratios were measured with MIMS; data Gardner and McCarthy (unpublished)

Benthic chambers; $\mathrm{N}_{2}$ fluxes estimated stoichiometrically; data from Gardner et al. (1993)

Sediment oxygen consumption and denitrification calculated from volumetric rates obtained in sediment columns (Rao et al. 2007)

Sediment core incubations; described in Aller et al. (1985)

Data compilation from Middelburg et al. (1997)

In situ benthic chambers; $\mathrm{N}_{2}$ fluxes measured with gas chromatography; data from Devol and Christensen (1993)

Oceanic In situ benthic chambers; $\mathrm{N}_{2}$ fluxes measured with gas chromatography; data from Devol et al. (1997) from Corpus Christi Bay and 2 from Old Woman Creek. Biological nitrogen fixation associated with autotrophic nitrogen fixers, such as cyanobacterial mats and seagrass beds, occurs in shallow subtropical and tropical sediments, and can be an important nitrogen source (Paerl and Zehr 2000). Nitrogen fixers in Old Woman Creek and Corpus Christi Bay are probably cyanobacteria (McCarthy et al. 2007, 2008). However, no cyanobacterial pigments were found in Narraganset Bay sediments, where high rates (3$5 \mathrm{mmol} \mathrm{N} \mathrm{m}{ }^{-2} \mathrm{~d}^{-1}$ ) were observed during the summer of 2006 (Fulweiler et al. 2007). The $\mathrm{N}_{2}$ : $\mathrm{Ar}$ 
Table 2 List of symbols and formulae for derived quantities

\begin{tabular}{|c|c|c|c|}
\hline Symbol & \multicolumn{2}{|l|}{ Description } & Unit \\
\hline$J_{\mathrm{N}_{2}}$ & \multicolumn{2}{|c|}{$\mathrm{N}_{2}$ flux across sediment-water interface due to sediment denitrification } & $\mathrm{mmol} \mathrm{N} \mathrm{m}{ }^{-2} \mathrm{~d}^{-1}$ \\
\hline$J_{\mathrm{O}_{2}}$ & \multicolumn{2}{|c|}{$\mathrm{O}_{2}$ flux across sediment-water interface due to sediment oxygen consumption } & $\mathrm{mmol} \mathrm{O} \mathrm{m}^{-2} \mathrm{~d}^{-1}$ \\
\hline$J_{\mathrm{NH}_{4}}$ & \multicolumn{2}{|c|}{$\mathrm{NH}_{4}^{+}$flux across sediment-water interface } & $\operatorname{mmol~} \mathrm{N} \mathrm{m}^{-2} \mathrm{~d}^{-1}$ \\
\hline$J_{\mathrm{NO}_{3}}$ & \multicolumn{2}{|c|}{$\mathrm{NO}_{3}{ }^{-}$flux across sediment-water interface } & $\mathrm{mmol} \mathrm{N} \mathrm{m}{ }^{-2} \mathrm{~d}^{-1}$ \\
\hline$J P_{\mathrm{NH}_{4}}$ & \multicolumn{2}{|c|}{ Production of $\mathrm{NH}_{4}^{+}$(ammonification rate) } & $\mathrm{mmol} \mathrm{N} \mathrm{m}{ }^{-2} \mathrm{~d}^{-1}$ \\
\hline$J P_{\mathrm{NO}_{3}}$ & \multicolumn{2}{|c|}{ Production of $\mathrm{NO}_{3}^{-}$(nitrification rate) } & $\mathrm{mmol} \mathrm{N} \mathrm{m}^{-2} \mathrm{~d}^{-1}$ \\
\hline$J P_{\mathrm{CO}_{2}}$ & \multicolumn{2}{|c|}{ Production of $\mathrm{CO}_{2}$ (total carbon oxidation rate) } & $\mathrm{mmol} \mathrm{C} \mathrm{m}{ }^{-2} \mathrm{~d}^{-1}$ \\
\hline$J P_{\mathrm{CO}_{2} ; \mathrm{DNF}}$ & \multicolumn{2}{|c|}{ Production of $\mathrm{CO}_{2}$ due to denitrification (carbon oxidation attributed to denitrification) } & $\mathrm{mmol} \mathrm{C} \mathrm{m}{ }^{-2} \mathrm{~d}^{-1}$ \\
\hline \multicolumn{2}{|c|}{ Derived quantities } & \multicolumn{2}{|l|}{ Applied to } \\
\hline \multirow{5}{*}{\multicolumn{2}{|c|}{$\begin{array}{l}J_{\mathrm{N}_{2}}=-J_{\mathrm{O}_{2}} / 6.625-J_{\mathrm{NO}_{3}}-J_{\mathrm{NH}_{4}} \\
J_{\mathrm{N}_{2}}=J P_{\mathrm{NH}_{4}}-J_{\mathrm{NH}_{4}}-J P_{\mathrm{NO}_{3}} \\
J P_{\mathrm{NO}_{3}}=J_{\mathrm{N}_{2}}+J_{\mathrm{NO}_{3}} \\
J P_{\mathrm{CO}_{2}}=(106 / 84.8) J_{\mathrm{N}_{2}}-J_{\mathrm{O}_{2}}-2 J P_{\mathrm{NO}_{3}} \\
J P_{\mathrm{CO}_{2} ; \mathrm{DNF}}=(106 / 84.8) J_{\mathrm{N}_{2}} / J P_{\mathrm{CO}_{2}}\end{array}$}} & \multirow{2}{*}{\multicolumn{2}{|c|}{$\begin{array}{l}\text { Data from Chesapeake Bay, University of Rhode Island mesocosms, Lake Champlain } \\
\text { East China Sea data }\end{array}$}} \\
\hline & & & \\
\hline & & \multicolumn{2}{|l|}{ All data points with $J_{\mathrm{N}_{2}}>0$ (i.e., with net denitrification) } \\
\hline & & \multicolumn{2}{|l|}{ All data points with $J_{\mathrm{N}_{2}}>0$} \\
\hline & & \multicolumn{2}{|l|}{ All data points with $J_{\mathrm{N}_{2}}>0$} \\
\hline
\end{tabular}

technique only measures the net $\mathrm{N}_{2}$ flux resulting from both denitrification and nitrogen fixation, thus masking the individual contributions of both processes. However, when combined with the isotope-pairing technique (An et al. 2001; Gardner et al. 2006), individual rates can be estimated simultaneously (with the caveat that rates may be sensitive to the bottomwater nitrate concentration and thus can be affected by the addition of isotopically labeled nitrate). Nitrogen fixation and denitrification occurred simultaneously in estuaries of the northern Gulf of Mexico at rates an order of magnitude above the observed net $\mathrm{N}_{2}$ flux (Gardner et al. 2006).

We estimated the nitrification rate as the sum of $\mathrm{N}_{2}$, $\mathrm{NO}_{3}{ }^{-}$and $\mathrm{NO}_{2}{ }^{-}$efflux from the sediment (data points with net $\mathrm{N}_{2}$ flux into the sediment were excluded from this calculation). On average (median), $17 \%$ of the total sediment oxygen consumption is due to nitrification of ammonium to nitrite or nitrate.

We assessed the potential contribution of bottom water nitrate to the observed denitrification flux (i.e., the potential for direct denitrification), assuming that any uptake of bottom-water nitrate by the sediment would be denitrified. This assumption will overestimate the importance of direct denitrification where dissimilatory nitrate reduction to ammonium is important. Even so, in most of our data points $(75 \%)$, the potential contribution of bottom-water nitrate to the observed denitrification flux was small $(<1 \%)$.
The oxidation of organic carbon in sediments occurs through aerobic mineralization as well as a range of anaerobic processes, including denitrification, and manganese, iron and sulfate reduction. The rate of carbon oxidation by all processes other than denitrification can be approximated as the difference between total sediment oxygen consumption and oxygen consumption during nitrification, assuming a respiratory coefficient of one (one mole of $\mathrm{O}_{2}$ is used in the oxidation of one mol of organic carbon; see Giblin et al. 1997; Risgaard-Petersen et al. 2004). We calculated total carbon oxidation as the sum of carbon oxidation by denitrification, assuming a C:N ratio of 106:84.8, and carbon oxidation by all other processes based on sediment oxygen consumption (Fig. $2 \mathrm{~b}$; see Table 2 for details on the calculation). The resulting median rate is $19 \mathrm{mmol} \mathrm{C} \mathrm{m}^{-2} \mathrm{~d}^{-1}$ and $11 \%$ (median) of this rate is supported by denitrification (Fig. 2c).

Environmental control on $\mathrm{N}$ cycling processes

A number of studies report relationships between sediment nitrogen cycling processes and environmental variables/characteristics. For example, a decrease of nitrification (and subsequent increase of ammonium efflux from the sediment) with decreasing concentrations of bottom-water oxygen has been observed (Klump and Martens 1987; Kemp et al. 1990; Caffrey et al. 1993). An increase in the mean ammonium flux 
Fig. 1 Histogram, mean (solid line) and median (dashed line) $N$ fluxes in our data set. Positive values indicate efflux from the sediments. Negative values indicate uptake by the sediments. Positive and negative outliers are collected in the bins for the largest and smallest value, respectively
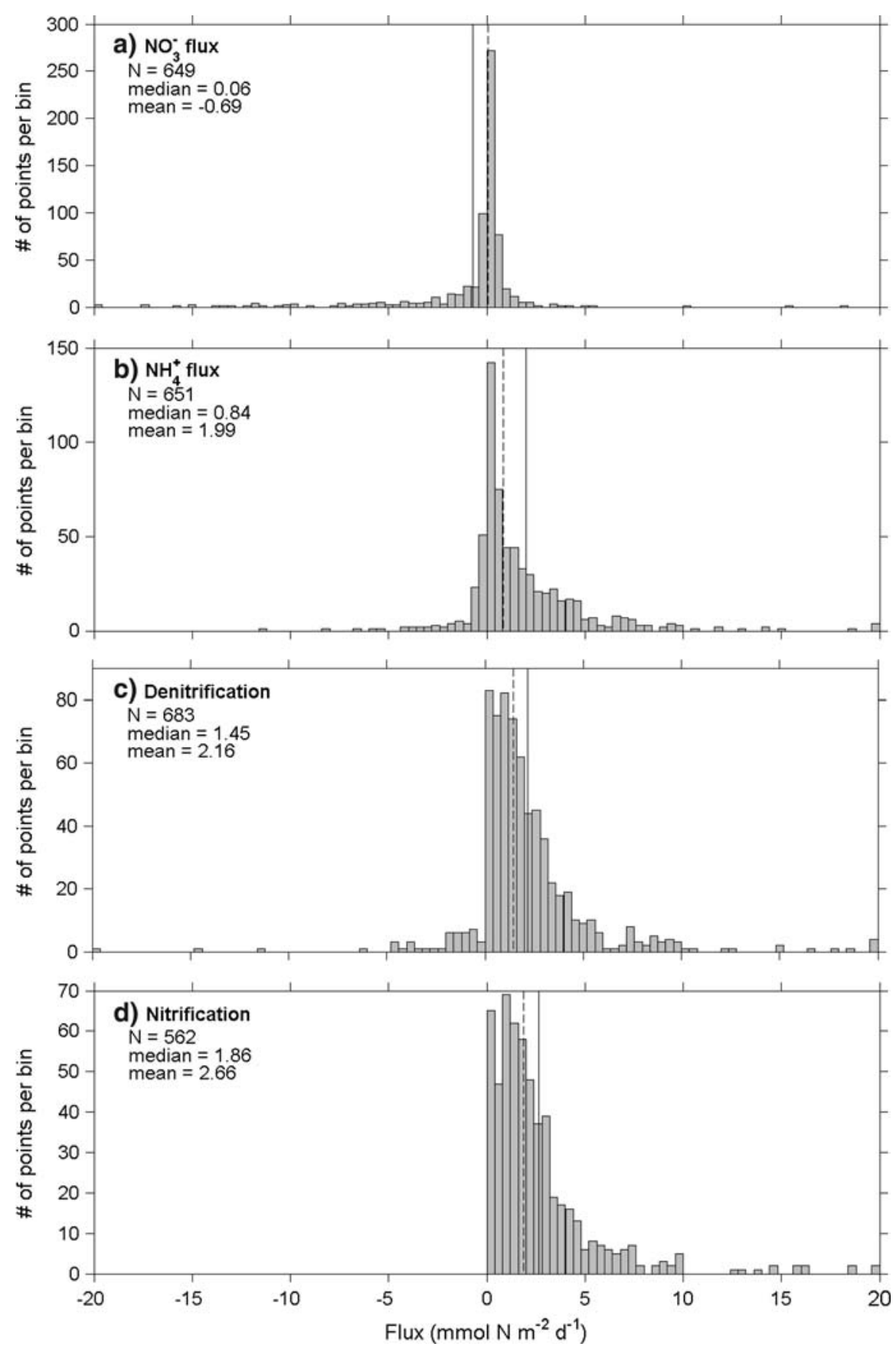

from the sediment with increasing salinity was observed in Texas estuaries and attributed to an increase in dissimilatory nitrate reduction to ammonium (DNRA) relative to denitrification (Gardner et al. 2006). An increase in total and direct denitrification was related to increasing concentrations of nitrate in the bottom water (Kana et al. 1998 and references therein). We used our data compilation, which spans a range of systems and environmental conditions, to assess whether these relationships are robust across systems.

Bottom-water oxygen concentrations in our data set range between 62 and $440 \mathrm{mmol} \mathrm{O}_{2} \mathrm{~m}^{-3}$ with a median of $203 \mathrm{mmol} \mathrm{O}_{2} \mathrm{~m}^{-3}$. When comparing the 
Fig. 2 Histogram, mean (solid line) and median (dashed line) sediment oxygen consumption (SOC), total carbon oxidation and the fraction of carbon oxidation carried out by denitrifiers in our data set. Positive outliers are collected in the bins for the largest value
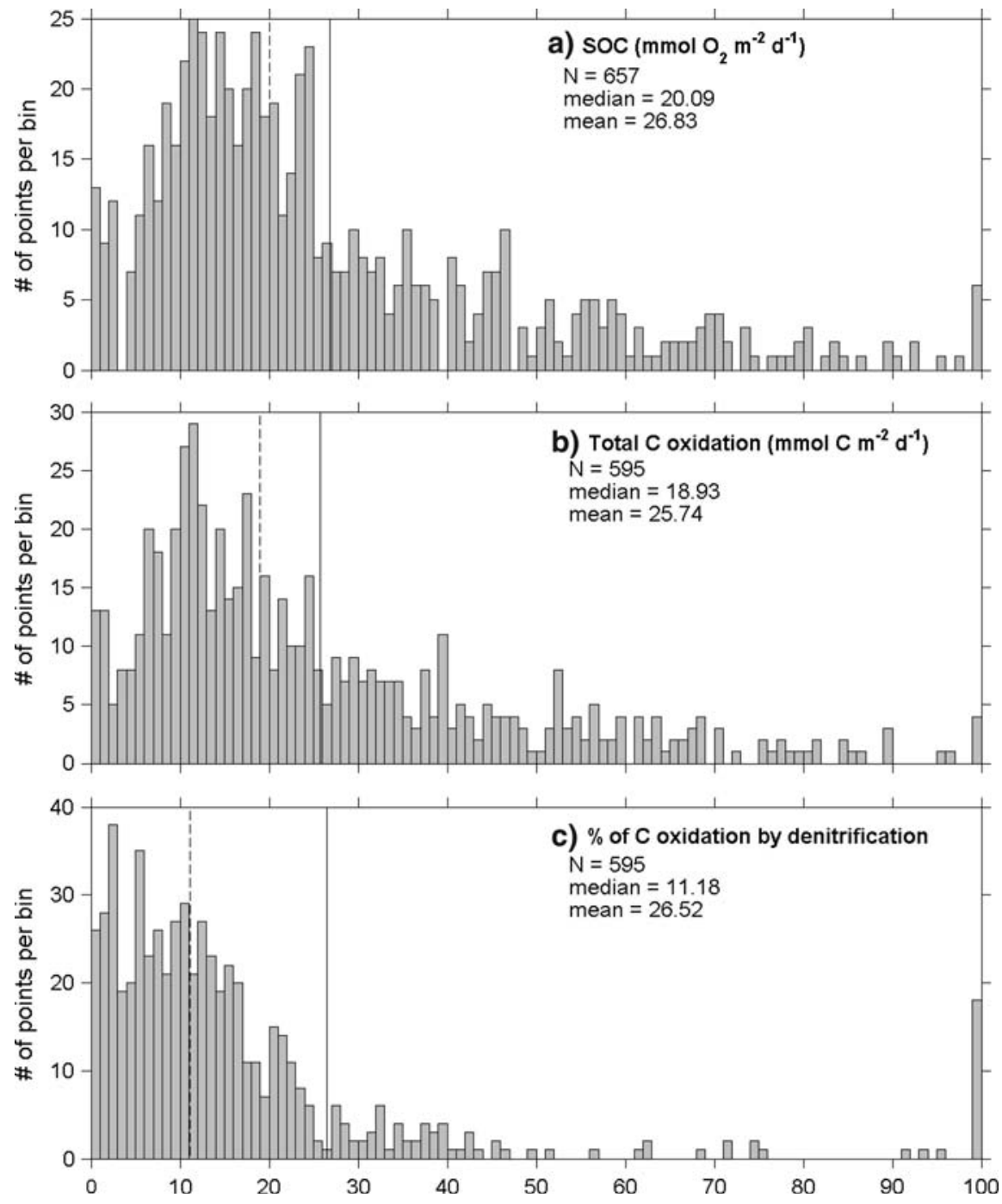

median nitrification fluxes for bottom water oxygen concentrations smaller and larger than $94 \mathrm{mmol}$ $\mathrm{O}_{2} \mathrm{~m}^{-3}$ (2.2 and $2.3 \mathrm{mmol} \mathrm{N} \mathrm{m} \mathrm{N}^{-2} \mathrm{~d}^{-1}$, respectively), only a small and statistically insignificant increase is seen, probably because we do not have a good representation of low oxygen environments in our data set.

We investigated whether ammonium fluxes increase with increasing salinity in our data set by comparing total ammonium efflux and the ammonium fraction of the total nitrogen flux from our two freshwater systems to the flux from Chesapeake Bay, Corpus Christi Bay and the Middle Atlantic Bight coastal regions (salinities of 0, 15-20, 24-28 and 3032 PSU, respectively; see Table 1). We found a small, statistically insignificant decrease in ammonium fluxes with increasing salinity. To account for differences in sediment type, nutrient loading and organic matter supply to the sediment between these systems, we also compared the ratio of ammonium efflux to total nitrogen flux and found an increase with increasing salinities, in agreement with the results from Texas estuaries (Gardner et al. 2006). However, the differences in median are not statistically significant; hence, no general conclusions about the relationship between ammonium fluxes and salinity can be drawn.

We found an increase of total denitrification with increasing bottom water nitrate concentrations as well as an increase in the ratio of sediment nitrate uptake to total denitrification (which one can interpret as an increase in the rate of direct denitrification). For bottom water nitrate concentrations below and above 
$40 \mathrm{mmol} \mathrm{N} \mathrm{m}^{-3}$, the median denitrification fluxes are 1.8 and $2.6 \mathrm{mmol} \mathrm{N} \mathrm{m}^{-2} \mathrm{~d}^{-1}$, respectively. The difference is statistically highly significant $(P<0.0001)$. The median ratios of sediment nitrate uptake to total denitrification are 0 and 0.83 for bottom-water nitrate concentrations below and above $40 \mathrm{mmol} \mathrm{N} \mathrm{m}^{-3}$, respectively (significant at $P<0.001$ ).

\section{Application of data to models}

Denitrification in aquatic sediments has long been recognized as an important sink of fixed nitrogen. Approaches to modeling denitrification are crucial for a meaningful extrapolation of local estimates of denitrification to larger spatial and temporal scales, as well as for inclusion of this process in predictive models of aquatic ecosystems. Two principal approaches for describing the impacts of sediment denitrification on nitrogen fluxes across the sedimentwater interface exist and have been described above ('Model approaches'): empirical parameterizations and detailed mechanistic descriptions of diagenetic processes. Integration of these model approaches with measurements is crucial, but qualitatively different for both approaches. While empirical parameterizations are inherently data-based, the diagenetic models do not use observations directly. Diagenetic models require specification of a number of model parameters, the validity of which can typically only be estimated a posteriori, by comparing model predictions with observations.

Our data compilation allows us to look for relationships between variables that could potentially be used to improve predictive parameterizations of denitrification, to reevaluate published parameterizations, and to evaluate the denitrification rates predicted by diagenetic models. While diagenetic models have typically been applied to specific sites, the model of Soetaert et al. (1996b) has been generalized to cover the global scale by means of a meta-analysis (Middelburg et al. 1996). We will use this meta-analysis below as an example of a diagenetic model. We first discuss a multivariate regression analysis of our data set and reevaluate the regression between denitrification and sediment oxygen consumption; we then analyze differences between nitrogen and phosphate fluxes across the sediment-water interface; finally, we discuss qualitative differences between parameterizations and diagenetic models by contrasting denitrification fluxes predicted by a diagenetic model (Middelburg et al. 1996; Soetaert et al. 1996b) with an empirical relationship derived from our data set.

\section{Regression analysis}

The existence of robust relationships between nitrogen cycling processes and environmental variables, such as organic matter supply, sediment oxygen consumption, benthic community structure, sediment type, seasonality or trophic status, and across a diversity of systems would underpin predictive modeling of denitrification beyond the regional scale of individual studies. We assessed whether previously reported relationships, like a decrease of nitrification for low bottom water oxygen concentrations, an increase of ammonium efflux with increasing salinity, or an increase in the contribution of direct to total denitrification with increasing bottom water nitrate concentrations are expressed in our data compilation. The only relationship we found to be robust was the increase of direct denitrification with increasing bottom water nitrate ('Environmental control on $\mathrm{N}$ cycling processes').

Parameterizations of sediment denitrification have relied on correlations with sediment oxygen consumption (SOC), but the inclusion of additional factors like the bottom water concentrations of nitrate and oxygen in parameterizations could potentially improve the predictive skill of parameterizations. We assessed this possibility for the variables in our data compilation by deriving a multiple regression between coupled denitrification $\left(J_{\mathrm{N}_{2}}\right.$ in $\left.\mathrm{mmol} \mathrm{N} \mathrm{m} \mathrm{N}^{-2} \mathrm{~d}^{-1}\right)$ and the independent variables $\mathrm{SOC}\left(J_{\mathrm{O}_{2}}\right.$ in $\mathrm{mmol}$ $\left.\mathrm{O}_{2} \mathrm{~m}^{-2} \mathrm{~d}^{-1}\right)$, the fluxes of phosphate $\left(J_{\mathrm{PO} 4}\right.$ in mmol $\left.\mathrm{P} \mathrm{m} \mathrm{m}^{-2} \mathrm{~d}^{-1}\right)$, nitrate $\left(J_{\mathrm{NO}_{3}}\right.$ in $\left.\mathrm{mmol} \mathrm{N} \mathrm{m} \mathrm{m}^{-2} \mathrm{~d}^{-1}\right)$, ammonium $\left(J_{\mathrm{NH}_{4}}\right.$ in mmol N m$\left.{ }^{-2} \mathrm{~d}^{-1}\right)$ and the bot-

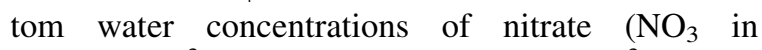
mmol $\left.\mathrm{N} \mathrm{m}^{-3}\right)$ and oxygen $\left(\mathrm{O}_{2}\right.$ in $\left.\mathrm{mmol} \mathrm{m}^{-3}\right)$ as

$$
\begin{aligned}
J_{\mathrm{N}_{2}}= & -1.7229-0.079895 J_{\mathrm{O}_{2}}+1.9497 J_{\mathrm{PO}_{4}} \\
& -0.4435 J_{\mathrm{NO}_{3}}-0.14878 J_{\mathrm{NH}_{4}} \\
& -0.0082778 \mathrm{NO}_{3}+0.00687808 \mathrm{O}_{2} .
\end{aligned}
$$

The residuals and standardized partial regression coefficients are shown in Fig. 3. The standardized partial regression coefficients are all in units of standard deviation and can be compared directly to 
Fig. 3 Residuals (top panel) and standardized partial regression coefficients (bottom panel) for multiple regression of coupled nitrificationdenitrification flux. Independent variables are sediment oxygen consumption (SOC), sediment-water fluxes of phosphate, nitrate and ammonium, and bottomwater concentrations of nitrate and oxygen (see 'Regression analysis' in 'Results and discussion' for regression coefficients). Regression coefficients were standardized by multiplying with the ratio of standard deviations of the independent and dependent variable. Standardized partial regression coefficients can be compared directly to assess which independent variables are most effective in determining the denitrification flux
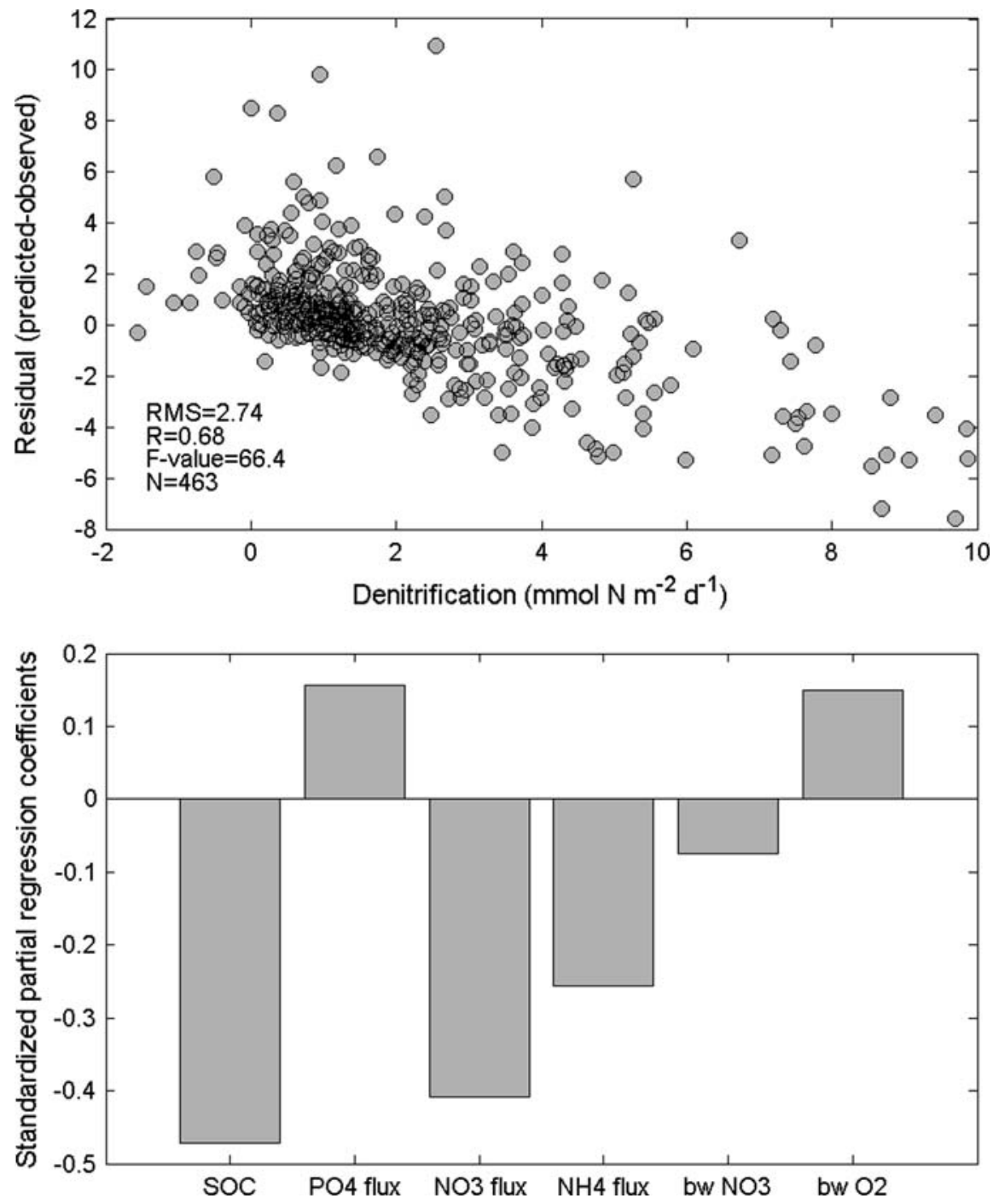

determine the relative effectiveness of the independent variables as predictors of the dependent variable, $J_{\mathrm{N}_{2}}$. The most effective variables are sediment oxygen consumption and the sediment-water flux of nitrate. In contrast to our expectation, the bottom-water concentrations of nitrate and oxygen are the least effective predictors in the overall regression. By iteratively removing the least effective independent variable (i.e., the variable with the smallest standardized partial regression), we determined regressions for smaller subsets of the independent variables. It became apparent that the bottom water concentrations (i.e., variables that are comparatively easy to measure or estimate) added little predictive power (the $R$ value decreased insignificantly, from 0.68 to 0.67 ).
We also derived a linear regression between the coupled nitrification-denitrification flux and sediment oxygen consumption using all data points in our data set (Fig. 4, red line) and using only data points where no net $\mathrm{N}$ fixation occurs (Fig. 4, green line). Both relationships are statistically significant at the $1 \%$ level $(F$ test). The slope of this relationship (0.09) is comparable to but lower than Seitzinger et al.'s (2006) slope of 0.12. This discrepancy is not surprising given the larger data set used here. The relatively low $R$ value of 0.55 in our regression is likely due to differences in sediment type and biogeochemical environment across systems. For example, variations in the relative importance of canonical denitrification and anammox to the total rate of $\mathrm{N}_{2}$ production would 
Fig. 4 Linear regression (red line) of denitrification and sediment oxygen consumption (SOC) for all of our data points (gray dots) and excluding data points with net $\mathrm{N}_{2}$ flux into the sediment, i.e., when net $N$ fixation is occurring (green line, with 50\% confidence limits as dashed lines) in comparison with Seitzinger et al. (2006) regression (blue line) and Middelburg et al. (1996) parameterization (magenta line). Note that

Middelburg's

parameterization relates carbon flux to denitrification flux. We converted from carbon flux to SOC, assuming a $1 \mathrm{~mol}$ $\mathrm{C}: 1 \mathrm{~mol} \mathrm{O}_{2}$ quotient

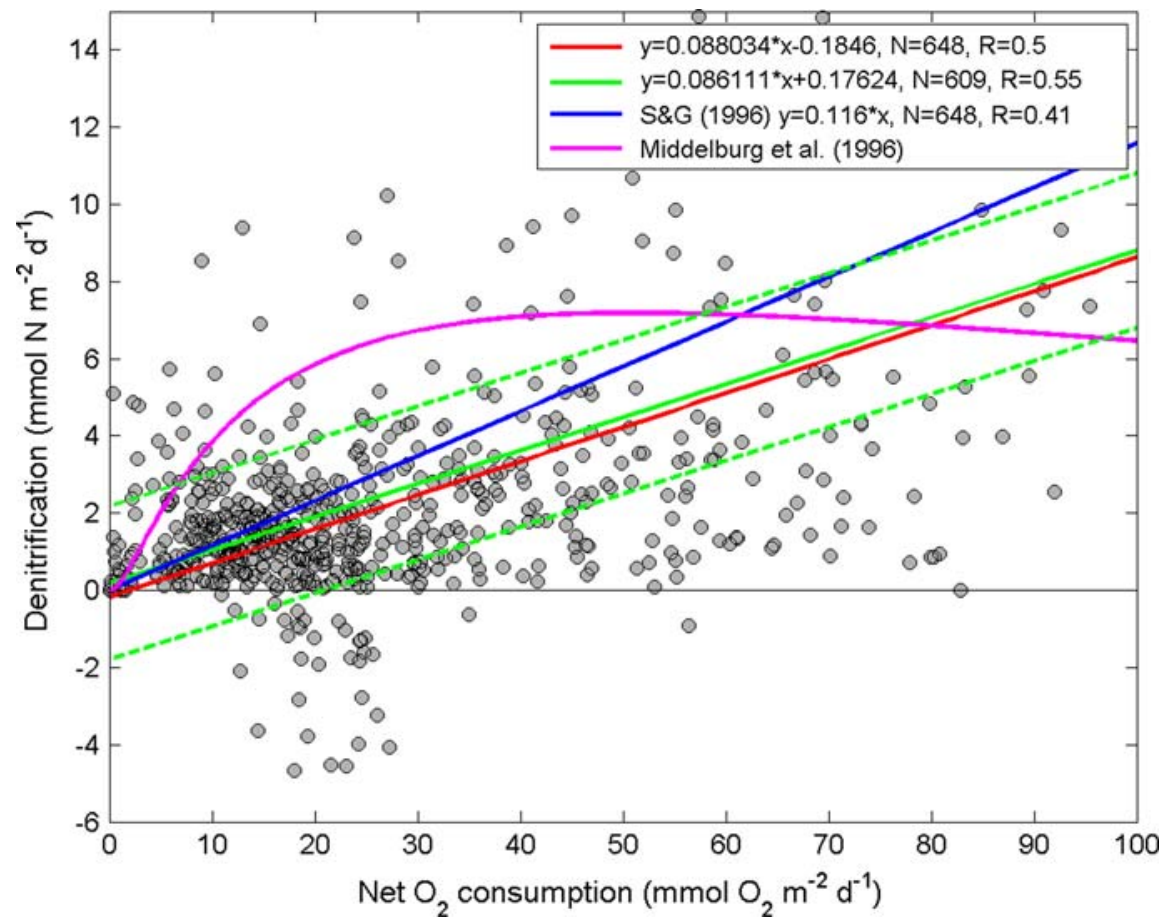

lead to a different stoichiometry and thus different regression coefficients. The most important difference between anammox and canonical denitrification is that anammox does not involve oxidation of organic matter. Anammox is not directly tied to carbon oxidation but depends on the supply of $\mathrm{NO}_{3}{ }^{-}$and $\mathrm{NO}_{2}{ }^{-}$that is mostly derived from nitrification of ammonium produced in the respiration of organic matter (an indirect link to organic matter oxidation). Hence, the C-to-O-to- $\mathrm{N}$ stoichiometry of $\mathrm{N}_{2}$ production via the pathway of ammonification $\rightarrow$ nitrification $\rightarrow$ canonical denitrification is different from that of $\mathrm{N}_{2}$ production via ammonification $\rightarrow$ nitrification $\rightarrow$ anammox. Our data set is not comprehensive enough to assess the relative importance of both pathways. One would need coincident measurements of sediment-water fluxes of $\mathrm{CO}_{2}, \mathrm{O}_{2}$ and all the nitrogen species.

Phosphate fluxes

The fate of mineralized phosphate in sediments is qualitatively different to that of mineralized nitrogen, in that phosphate is bound to iron and manganese minerals under oxic conditions. It has been suggested that the extent to which phosphate can be bound in sediments is dramatically different between freshwater and brackish/marine systems, and that phosphate is essentially a conservative tracer of benthic decomposition in marine sediments, but is strongly retained in freshwater sediments (Caraco et al. 1990). This apparent difference was suggested to explain the observed differences in nutrient limitation between marine and freshwater systems, with nitrogen often limiting in marine systems and phosphorus more typically limiting in freshwater systems (Caraco et al. 1990).

We analyzed the $N^{*}\left(N^{*}=N-16 \times P\right)$ of sediment-water nutrient fluxes to see whether our data are consistent with the notion that phosphate is a conservative tracer of benthic decomposition in marine sediments and whether there are systematic differences in the stoichiometry of the nutrient return flux from sediments between freshwater and marine systems. The $N^{*}$ values of total nitrogen $\left(\mathrm{N}_{2}+\mathrm{NO}_{3}{ }^{-}+\mathrm{NH}_{4}{ }^{+}\right)$flux versus phosphate flux are shown in Fig. 5 for all our data points and separately for freshwater and marine systems. In all three cases the mean $N^{*}$ is significantly larger than zero which corresponds to the canonical Redfield ratio of 16 ( $t$-test, $P \ll 0.01$ ). Our data thus indicates that phosphate is retained more strongly than nitrogen in the sediments represented in our data set (all are overlaid by oxic bottom waters) and hence not a 
Fig. 5 Histogram, mean (solid line) and median (dashed line) for $N^{*}$ of total remineralized nitrogen $\left(\mathrm{NH}_{4}{ }^{+}+\mathrm{NO}_{3}{ }^{-}+\mathrm{N}_{2}\right)$ versus phosphate flux $\left(N^{*}=N-16 \times \mathrm{P}\right)$ for all data points (top), freshwater only (middle) and marine systems only (bottom). The $N^{*}$ of zero corresponds to the Redfield ratio and is indicated by the dotted line. Outliers that fall outside the axis range are collected in the largest and smallest bins
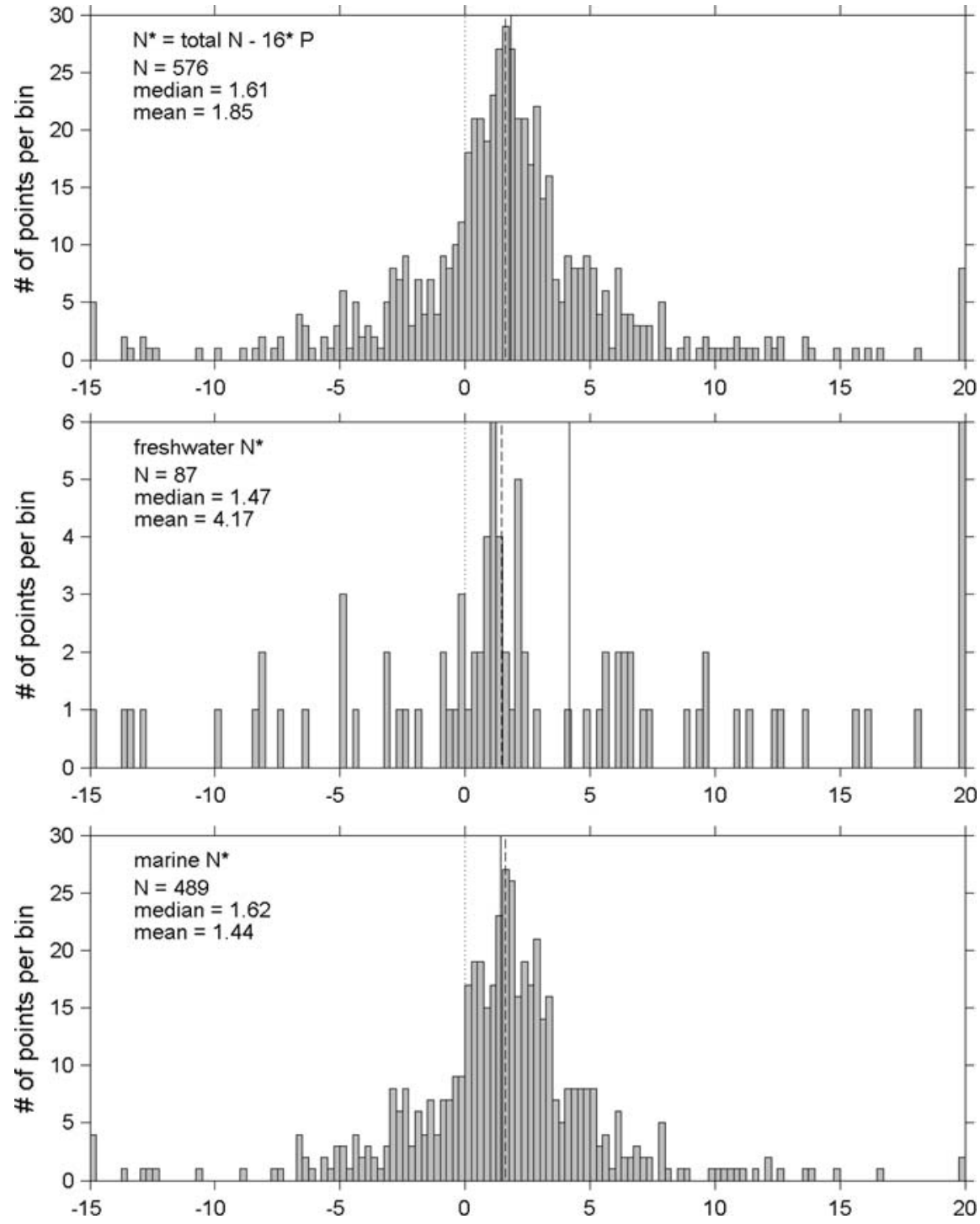

conservative tracer of benthic remineralization. However, the analysis in Fig. 5 includes nitrogen that is returned as biologically unavailable $\mathrm{N}_{2}$ gas and thus not directly relevant for assessing nutrient limitation. We repeated the analysis for $N^{*}$ calculated from the bioavailable nitrogen $\left(\mathrm{NO}_{3}{ }^{-}+\mathrm{NH}_{4}{ }^{+}\right)$flux versus phosphate flux (Fig. 6). In this case the $N^{*}$ values are not statistically different from zero ( $t$-test, $1 \%$ significance level). In other words the stoichiometry of nutrient fluxes from the sediment is statistically not significantly different from the Redfield ratio of 16 . Our data hence suggest that both processes, phosphate retention in sediments and nitrogen removal through denitrification, contribute to the $\mathrm{N}: \mathrm{P}$ stoichiometry of bioavailable nutrients returned from the sediment. Since our analysis does not suggest consistent differences in the $\mathrm{N}: \mathrm{P}$ ratio of returned bioavailable nutrients, sediment nutrient fluxes do not appear to be a good explanation for the change in nutrient limitation from fresh to salt water, at least not in our data set which is limited for freshwater systems.

Diagenetic model versus parameterization

Detailed diagenetic models and simpler empirical parameterizations have different strengths and limitations. The empirical parameterizations are inherently 
Fig. 6 As in Fig. 5, but for bioavailable nitrogen flux $\left(\mathrm{NH}_{4}{ }^{+}+\mathrm{NO}_{3}{ }^{-}\right)$
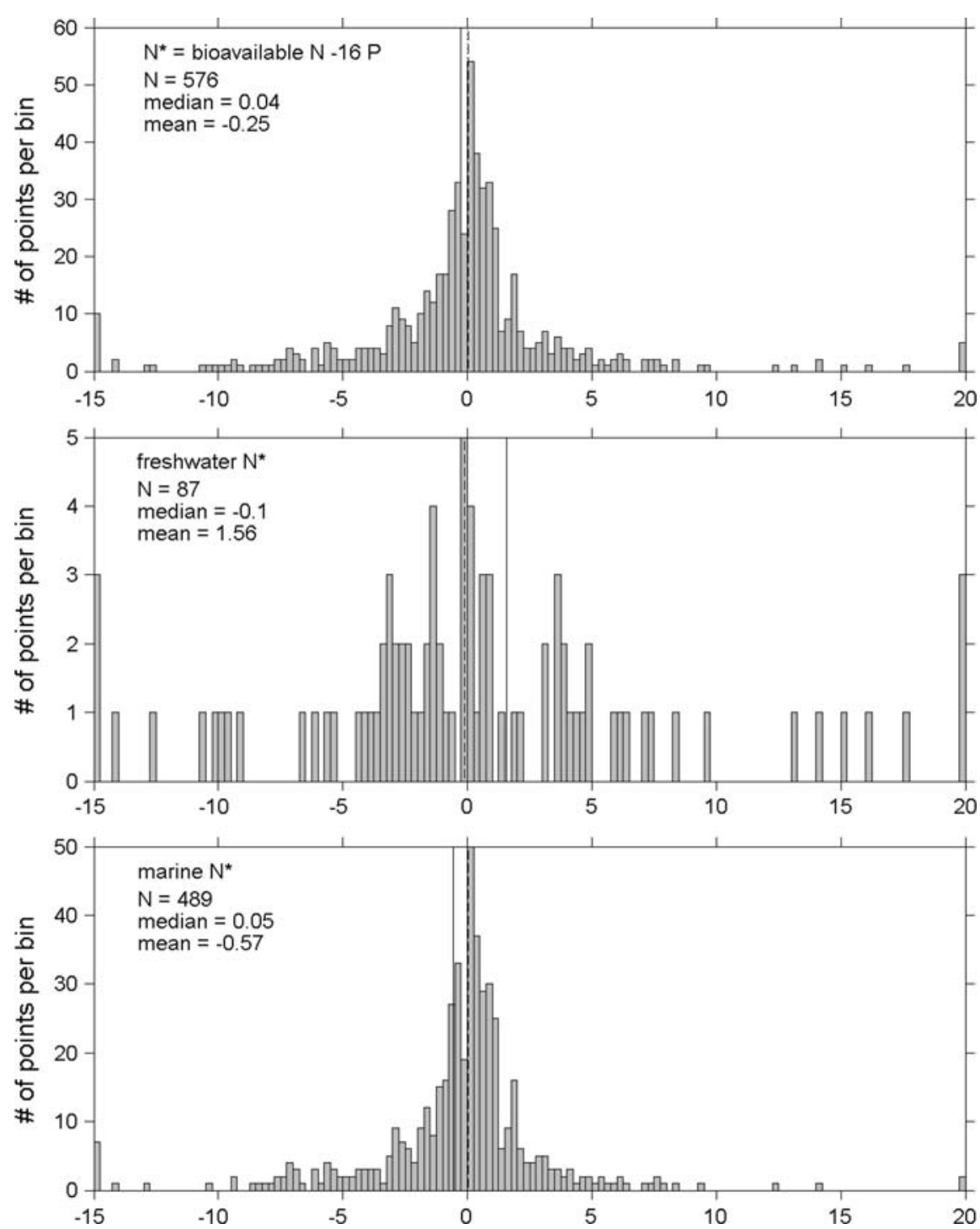

data-based, have the advantage of being conceptually simple and easy to implement, but they cannot capture strong non-linearities or system hysteresis, e.g., the non-linear response to nutrient reduction observed in the Chesapeake Bay (Kemp et al. 2005). Diagenetic models are based on a mechanistic understanding of sediment processes, include nonlinear feedback mechanisms and can include temporal dependencies such as delays or storage of organic matter. As such they are more flexible and have the potential to correctly predict system responses to changes in eutrophication status or oxygen supply; e.g., the Sediment Flux Model applied to data from a mesocosm eutrophication experiment (see our 'Layered dynamic models' subsection;
DiToro 2001). They can also be extremely useful tools to further our mechanistic understanding; e.g., the microzone model (see 'Microenvironments' subsection) can explain the counterintuitive observation of rapid denitrification observed in the presence of oxic pore water in continental shelf sands with very low pore water nitrate concentrations (Rao et al. 2007). On the other hand, these mechanistic models typically require detailed knowledge about parameter values, such as reaction kinetics and sediment characteristics. For example, the microzone denitrification model requires knowledge about the size, reactivity, and composition of reactive sediment microenvironments. Likewise, layered diagenetic models require a number 
of parameters describing reaction kinetics, sediment porosity and assumptions about organic matter lability.

Middelburg et al. (1996) applied the diagenetic model of Soetaert et al. (1996a, b) to the global ocean by assuming uniform values for rate, limitation and inhibition parameters, and a uniform porosity profile. However, their predicted denitrification rates show a markedly different behavior than our data compilation suggests and overestimate the observations for SOC rates, ranging from 5 to $50 \mathrm{mmol} \mathrm{O}_{2} \mathrm{~m}^{-2} \mathrm{~d}^{-1}$ (Fig. 4). Note that their parameterization relates denitrification to organic matter flux, which we considered equal to sediment oxygen consumption (assuming steady-state and a metabolic quotient of $1 \mathrm{~mol} \mathrm{C}: 1 \mathrm{~mol} \mathrm{O}_{2}$ ). Because of the observational and conceptual difficulties with sedimentation flux in shallow systems, we recommend using SOC instead of sedimentation flux when deriving parameterizations using denitrification measurements, although sedimentation flux is typically the relevant quantity predicted by ecosystem models coupled to hydrodynamic models or General Circulation Models. The poor agreement between the observed denitrification rates and the rates predicted by the diagenetic model may indicate that parameters and porosity profiles are not globally applicable, as had been assumed. This interpretation is consistent with our finding that bottom-water nitrate and oxygen concentrations were the least effective predictors in our data set when included in a multivariate regression between denitrification and SOC (they improved the coefficient of determination only insignificantly), while they were the most important drivers in determining denitrification in sensitivity studies with the diagenetic model (Soetaert et al. 1996a, b). Assessing whether this discrepancy is indeed due to differences like hydrographic setting, sediment type and benthic community across systems is beyond the scope of this study. In a systematic assessment, one would apply the diagenetic model to different sites that have detailed observations including pore water profiles available.

\section{Conclusions}

There are no conceptual or technical difficulties in applying empirical parameterizations or diagenetic models to large spatial scales. However, because diagenetic models are typically tuned to match observations at specific sites there is no guarantee they will make good predictors across larger spatial scales. The major difficulty thus lies in evaluating fluxes predicted by diagenetic models against observations. We compared denitrification rates predicted by a diagenetic model (Middelburg et al. 1996) with observations in our data compilation after converting the organic carbon sedimentation flux to sediment oxygen consumption units and found that the diagenetically predicted fluxes significantly overestimate observed fluxes. Systematic studies will be necessary to elucidate the underlying reasons; it is likely that regional adaptations of the model for different environments and sediment types will be necessary. This would require a spatially explicit characterization of benthic environments/sediment types, along with rate measurements in all characteristic environments.

Based on our analysis, we recommend using empirical regressions between SOC and denitrification for predicting denitrification in oxic bottom waters. We calculated the linear relationship between sediment denitrification and sediment oxygen consumption suggested by Seitzinger et al. (2006) for the larger data set compiled here and found a similar regression slope, but a much smaller coefficient of determination (Fig. 4). One reason for the uncertainty in our regression may be variations in the relative importance of canonical denitrification versus anammox across different systems, since the underlying stoichiometries are different. Inclusion of bottom water concentrations of nitrate and oxygen in a multivariate regression did not improve the coefficient of determination significantly.

For suboxic and anoxic bottom waters (oxygen concentrations below $63 \mathrm{mmol} \mathrm{O}_{2} \mathrm{~m}^{-3}$ ) strong feedbacks on elemental cycling can occur, but these conditions were not represented in our data set. Perhaps the most relevant feedback in this context is the inhibition of nitrification and thus denitrification at these low oxygen levels (Childs et al. 2002). A linear parameterization of SOC and denitrification cannot capture this response and a non-linear multivariate regression based either exclusively on measurements or on a combination of measurements and modelpredicted rates will be necessary for such cases.

Acknowledgments Discussions reflected in this paper were initiated in November 2006 at a Modeling Workshop organized by the Research Coordination Network on Denitrification 
(http://www.denitrification.org/). We thank the organizers and gratefully acknowledge the constructive criticism from Eric Davidson and two anonymous reviewers. We thank Jane Tucker for working up the data sets from Massachusetts Bay and Boston Harbor. Financial support for AEG to work on the manuscript came from NSF NSF-DEB-0423565. KF, DB and DDT acknowledge support from NOAA CHRP grant NA07NOS4780191. NOAA publication number 102.

\section{References}

Aller RC (1980) Quantifying solute distributions in the bioturbated zone of marine sediments by defining an average microenvironment. Geochim Cosmochim Acta 44(12): $1955-1965$

Aller RC (1988) Benthic fauna and biogeochemical processes in marine sediments: the role of burrow structures. In: Blackburn TH, Soerensen J (eds) Nitrogen cycling in coastal marine environments. Wiley, New York, pp 301-338

Aller RC, Mackin JE, Ullman WJ, Wang CH, Tsai SM, Jin JC et al (1985) Early chemical diagenesis, sediment-water solute exchange, and storage of reactive organic matter near the mouth of the Changjiang, East China Sea. Cont Shelf Res 4(1/2):227-251

Altabet MA, Francois R, Murray DW, Prell WL (1995) Climaterelated variations in denitrification in the Arabian Sea from sediment 15 N/14 N ratios. Nature 373(6514):506-509

An S, Gardner WS, Kana T (2001) Simultaneous measurement of denitrification and nitrogen fixation using isotope pairing with membrane inlet mass spectrometry analysis. Appl Environ Microbiol 67:1171-1178

Bender M, Jahnke R, Weiss R, Martin W, Heggie DT, Orchardo J et al (1989) Organic carbon oxidation and benthic nitrogen and silica dynamics in San Clemente Basin, a continental borderland site. Geochim Cosmochim Acta 53(3):685-697

Berner RA (1980) Early diagenesis: a theoretical approach. Princeton University Press, Princeton

Billen G, Garnier J (1999) Nitrogen transfers through the Seine drainage network: a budget based on the application of the Riverstrahler' model. Hydrobiologia 410:139-150

Billen G, Garnier J, Hanset P (1994) Modelling phytoplankton development in whole drainage networks: the Riverstrahler Model applied to the Seine river system. Hydrobiologia 289(1):119-137

Boudreau BP (1997) Diagenetic models and their implementation: modelling transport and reactions in aquatic sediments. Springer, Berlin

Boyer EW, Alexander RB, Parton WJ, Li C, Butterbach-Bahl $\mathrm{K}$, Donner SD et al (2006) Modeling denitrification in terrestrial and aquatic ecosystems at regional scales: current approaches and needs. Ecol Appl 16:2123-2142

Burdige DJ (2006) Geochemistry of marine sediments. Princeton University Press, Princeton

Caffrey JM, Sloth NP, Kaspar HF, Blackburn TH (1993) Effect of organic loading on nitrification and denitrification in a marine microcosm. FEMS Microbiol Ecol 12:159-167

Caraco N, Cole J, Likens GE (1990) A comparison of phosphorus immobilization in sediments of freshwater and coastal marine systems. Biogeochemistry 9(3):277290

Cerco CF, Seitzinger SP (1997) Measured and modeled effects of benthic algae on eutrophication in Indian River-Rehoboth Bay, Delaware. Estuar Coasts 20(1):231-248

Childs CR, Rabalais NN, Turner RE, Proctor LM (2002) Sediment denitrification in the Gulf of Mexico zone of hypoxia. Mar Ecol Prog Ser 240:285-290

Christensen JP (1994) Carbon export from continental shelves, denitrification and atmospheric carbon dioxide. Cont Shelf Res 14(5):547-576

Cornwell J, Owens M (1999) Benthic phosphorus cycling in Lake Champlain: results of an integrated field sampling/ water quality modeling study. Part B: Field studies. Lake Champlain Basin Program. Horn Point Laboratory, Cambridge MD. Technical report TS-168-98

Cowan JLW, Boynton WR (1996) Sediment-water oxygen and nutrient exchanges along the longitudinal axis of Chesapeake Bay: seasonal patterns, controlling factors and ecological significance. Estuaries 19(3):562-580

Dalsgaard T, Canfield DE, Petersen J, Thamdrup B, AcunaGonzalez J (2003) $\mathrm{N}_{2}$ production by the anammox reaction in the anoxic water column of Golfo Dulce, Costa Rica. Nature 422(6932):606-608

Devol AH (2008) Chapter 6: Denitrification including anammox. In: Capone D, Carpenter E, Mullholland M, Bronk D (eds) Nitrogen in the marine environment. Elsevier, Amsterdam, pp 263-302

Devol AH, Christensen JP (1993) Benthic fluxes and nitrogen cycling in sediments of the continental margin of the eastern North Pacific. J Mar Res 51:345-372

Devol AH, Codispoti LA, Christensen JP (1997) Summer and winter denitrification rates in western Arctic shelf sediments. Cont Shelf Res 17(9):1029-1050

DiToro DM (2001) Sediment flux modeling. Wiley-Interscience, New York

DiToro DM, Fitzpatrick JJ (1993) Chesapeake Bay sediment flux model. US EPA Contract Report, Annapolis

Emery K (1968) Relict sediments on continental shelves of world. AAPG Bull 52(3):445-464

Engström P, Dalsgaard T, Hulth S, Aller RC (2005) Anaerobic ammonium oxidation by nitrite (anammox): implications for $\mathrm{N}_{2}$ production in coastal marine sediments. Geochim Cosmochim Acta 69(8):2057-2065

Falkowski PG (1997) Evolution of the nitrogen cycle and its influence on the biological sequestration of $\mathrm{CO}_{2}$ in the ocean. Nature 387:272-275

Fennel K, Follows M, Falkowski PG (2005) The co-evolution of the nitrogen, carbon and oxygen cycles in the Proterozoic Ocean. Am J Sci 305:526-545

Fennel K, Wilkin J, Levin J, Moisan J, O’Reilly J, Haidvogel D (2006) Nitrogen cycling in the Middle Atlantic Bight: Results from a three-dimensional model and implications for the North Atlantic nitrogen budget. Global Biogeochemical Cycles 20, GB3007, doi:10.1029/2005GB002456

Fulweiler RW (2007) Climate impacts on benthic-pelagic coupling and biogeochemistry in Narragansett Bay, RI. $\mathrm{PhD}$ Dissertation, University of Rhode Island

Fulweiler RW, Nixon SW (2008) Responses of benthic-pelagic coupling to climate change in a temperate estuary. Hydrobiologia (in press) 
Fulweiler R, Nixon S, Buckley B, Granger S (2007) Reversal of the net dinitrogen gas flux in coastal marine sediments. Nature 448:180-182

Galloway JN, Aber JD, Erisman JW, Seitzinger SP, Howarth RW, Cowling EB et al (2003) The nitrogen cascade. Bioscience 53(4):341-356

Gardner WS, Briones EE, Kaegi EC, Rowe GT (1993) Ammonium excretion by benthic invertebrates and sediment-water nitrogen flux in the Gulf of Mexico near the Mississippi River plume. Estuaries 16(4):799-808

Gardner WS, McCarthy MJ, An S, Sobolev D, Sell KS, Brock D (2006) Nitrogen fixation and dissimilatory nitrate reduction to ammonium (DNRA) support nitrogen dynamics in Texas estuaries. Limnol Oceanogr 51(1): $558-568$

Garnier J, Billen G, Coste M (1995) Seasonal succession of diatoms and chlorophyceae in the drainage network of the Seine River: Observations and modeling. Limnol Oceanogr 40(4):750-765

Giblin AE, Hopkinson CS, Tucker J (1997) Benthic metabolism and nutrient cycling in Boston Harbor, Massachusetts. Estuaries 20:346-364

Gold AJ, Jacinthe PA, Groffman PM, Wright WR, Puffer RH (1998) Patchiness in groundwater nitrate removal in a riparian forest. Environ Qual 27:146-155

Harrison J, Maranger R, Alexander RB, Cornwell J, Giblin A, Jacinthe PA, et al. (2008) The regional and global significance of nitrogen removal in lakes and reservoirs. Biogeochemistry. doi:10.1007/s10533-008-9272-x

Huettel M, Webster IT (2001) Advective flow in permeable sediments. In: Boudreau BP, Jørgensen BB (eds) The benthic boundary layer: transport processes and biogeochemistry. Oxford University Press, Oxford, pp 144-179

Jacinthe PA, Groffman PM, Gold AJ, Mosier A (1998) Patchiness in microbial nitrogen transformations in groundwater in a riparian forest. J Environ Quality 27: $156-164$

Jahnke R (1985) A model of microenvironments in deep-sea sediments: formation and effects on pore water profiles. Limnol Oceanogr 30(5):956-965

Jahnke RA, Emerson SR, Murray JW (1982) A model of oxygen reduction, denitrification, and organic matter mineralization in marine sediments. Limnol Oceanogr 27(4):610-623

Jahnke RA, Richards M, Nelson J, Robertson C, Rao A, Jahnke D (2005) Organic matter remineralization and pore water exchange rates in permeable South Atlantic Bight continental shelf sediments. Contl Shelf Res 25:1433-1452

Kana TM, Darkangelo C, Hunt MD, Oldham JB, Bennett GE, Cornwell JC (1994) Membrane inlet mass spectrometer for rapid high-precision determination of $\mathrm{N}_{2}, \mathrm{O}_{2}$, and $\mathrm{Ar}$ in environmental water samples. Anal Chem 66(23): 4166-4170

Kana TM, Sullivan MB, Cornwell JC, Groszkowski KM (1998) Denitrification in estuarine sediments determined by membrane inlet mass spectrometry. Limnol Oceanogr 43(2):334-339

Kemp WM, Sampou P, Caffrey J, Mayer M, Henriksen K, Boynton WR (1990) Ammonium recycling versus denitrification in Chesapeake Bay sediments. Limnol Oceanogr 35(7):1545-1563
Kemp WM, Boynton WR, Adolf JE, Boesch DF, Boicourt WC, Brush G et al (2005) Eutrophication of Chesapeake Bay: historical trends and ecological interactions. Mar Ecol Prog Ser 303:1-29

Klump JV, Martens CS (1987) Biogeochemical cycling in an organic-rich coastal marine basin. 5 . Sedimentary nitrogen and phosphorus budgets based upon kinetic models mass balaces, and the stoichiometry of nutrient regeneration. Geochim Cosmochim Acta 51(5):1161-1173

Kuypers MM, Sliekers AO, Lavik G, Schmid M, Jorgensen BB, Kuenen JG et al (2003) Anaerobic ammonium oxidation by anammox bacteria in the Black Sea. Nature 422(6932):608-611

Kuypers MMM, Lavik G, Woebken D, Schmid M, Fuchs BM, Amann R et al (2005) Massive nitrogen loss from the Benguela upwelling system through anaerobic ammonium oxidation. Proc Natl Acad Sci USA 102(18):6478-6483

Laursen AE, Seitzinger SP (2002) The role of denitrification in nitrogen removal and carbon mineralization in MidAtlantic Bight sediments. Cont Shelf Res 22:1397-1416

McCarthy MJ, Gardner WS, Lavrentyev PJ, Moats KM, Jochem FJ, Klarer DM (2007) Effects of hydrological flow regime on sediment-water interface and water column nitrogen dynamics in a Great Lakes coastal wetland (Old Woman Creek, Lake Erie). J Great Lakes Res 33(1):219

McCarthy M, McNeal K, Morse J, Gardner W (2008) Bottomwater hypoxia effects on sediment-water interface nitrogen transformations in a seasonally hypoxic, shallow bay (Corpus Christi Bay, Texas, USA). Estuar Coasts 31:521531. doi: 10.1007/s12237-008-9041-Z

Meissner KJ, Galbraith ED, Völker C (2005) Denitrification under glacial and interglacial conditions: A physical approach. Paleoceanography 20(3):PA3001

Middelburg JJ, Soetaert K, Herman PMJ, Heip C (1996) Denitrification in marine sediments: a model study. Global Biogeochem Cyc 10:661-673

Middelburg JJ, Soetaert K, Herman PMJ (1997) Empirical relationships for use in global diagenetic models. DeepSea Res I 44(2):327-344

Moore JK, Doney SC (2007) Iron availability limits the ocean nitrogen inventory stabilizing feedbacks between marine denitrification and nitrogen fixation. Global Biogeochemical Cycles 21. doi:10.1029/2006GB002762

Mulder A, van de Graaf AA, Robertson LA, Kuenen JG (1995) Anaerobic ammonium oxidation discovered in a denitrifying fluidized bed reactor. FEMS Microbiol Ecol 16(3): 177-183

Naqvi SW, Jayakumar DA, Narvekar PV, Naik H, Sarma VV, D'Souza W et al (2000) Increased marine production of $\mathrm{N}_{2} \mathrm{O}$ due to intensifying anoxia on the Indian continental shelf. Nature 408(6810):346-349

Oviatt CA, Keller AA, Sampou PA, Beatty LL (1986) Patterns of productivity during eutrophication: a mesocosm experiment. Mar Ecol Prog Ser 28(1-2):69-80

Paerl H, Zehr J (2000) Marine nitrogen fixation. In: Kirchman DL (ed) Microbial ecology of the oceans. Wiley-Liss, Wilmington, pp 387-426

Parkin TB (1987) Soil microsites as a source of denitrification variability. Soil Sci Soc Am J 51:1194-1199

Rao AMF, McCarthy MJ, Gardner WS, Jahnke RA (2007) Respiration and denitrification in permeable continental 
shelf deposits on the South Atlantic Bight: rates of carbon and nitrogen cycling from sediment column experiments. Cont Shelf Res 27(13):1801-1819

Richards FA, Cline JD, Broenkow WW, Atkinson LP (1965) Some consequences of the decomposition of organic matter in Lake Nitinat, an Anoxic Fjord. Limnol Oceanogr 10:185-201

Risgaard-Petersen N, Meyer RL, Schmid M, Jetten MSM, Enrich-Prast A, Rysgaard S et al (2004) Anaerobic ammonium oxidation in an estuarine sediment. Aquat Microb Ecol 36(3):293-304

Ruelland D, Billen G, Brunstein D, Garnier J (2007) SENEQUE: a multi-scaling GIS interface to the Riverstrahler model of the biogeochemical functioning of river systems. Sci Total Environ 375:257-273

Seitzinger S, Harrison JA, Bohlke JK, Bouwman AF, Lowrance R, Peterson B et al (2006) Denitrification across landscapes and waterscapes: a synthesis. Ecol Appl 16(6):2064-2090

Soetaert K, Herman PMJ, Middelburg JJ (1996a) Dynamic response of deep-sea sediments to seasonal variations: a model. Limnol Oceanogr 41(8):1651-1668

Soetaert K, Herman PMJ, Middelburg JJ (1996b) A model of early diagenetic processes from the shelf to abyssal depths. Geochim Cosmochim Acta 60(6):1019-1040

Soetaert K, Middelburg JJ, Herman PMJ, Buis K (2000) On the coupling of benthic and pelagic biogeochemical models. Earth-Sci Rev 51:173-201
Thamdrup B, Dalsgaard T (2002) Production of $\mathrm{N}_{2}$ through anaerobic ammonium oxidation coupled to nitrate reduction in marine sediments. Appl Environ Microbiol 68(3):1312-1318

Thibodeaux LJ, Boyle JD (1987) Bedform-generated convective transport in bottom sediment. Nature 325(6102):341343

Thouvenot M, Billen G, Garnier J (2007) Modelling nutrient exchange at the sediment-water interface of river systems. J Hydrology 341(1-2):55-78

Trimmer M, Nicholls JC, Deflandre B (2003) Anaerobic ammonium oxidation measured in sediments along the thames estuary, United Kingdom. Appl Environ Microbiol 69(11):6447-6454

Trimmer M, Nicholls JC, Morley N, Davies CA, Aldridge J (2005) Biphasic behavior of anammox regulated by nitrite and nitrate in an estuarine sediment. Appl Environ Microbiol 71(4):1923-1930

Vanderborght JP, Wollast R, Billen G (1977a) Kinetic models of diagenesis in disturbed sediments. Part 1. Mass transfer properties and silica diagenesis. Limnol Oceanogr 22(5): 787-793

Vanderborght JP, Wollast R, Billen G (1977b) Kinetic models of diagenesis in disturbed sediments. Part 2. Nitrogen diagenesis. Limnol Oceanogr 22(5):794-803 